\title{
Bioaccessibility and Bioavailability of Minerals in Relation to a Healthy Gut Microbiome
}

\author{
Viktor Bielik $^{1, *}$ (D) and Martin Kolisek ${ }^{2}$ \\ 1 Department of Biological and Medical Science, Faculty of Physical Education and Sport, Comenius University \\ in Bratislava, 81469 Bratislava, Slovakia \\ 2 Biomedical Center Martin, Jessenius Faculty of Medicine in Martin, Comenius University in Bratislava, \\ 03601 Martin, Slovakia; martin.kolisek@uniba.sk \\ * Correspondence: viktor.bielik@uniba.sk
}

Citation: Bielik, V.; Kolisek, M. Bioaccessibility and Bioavailability of Minerals in Relation to a Healthy Gut Microbiome. Int. J. Mol. Sci. 2021, 22, 6803. https://doi.org/10.3390/ ijms 22136803

Academic Editor: Elena Azzini

Received: 28 April 2021

Accepted: 21 June 2021

Published: 24 June 2021

Publisher's Note: MDPI stays neutral with regard to jurisdictional claims in published maps and institutional affiliations.

Copyright: (c) 2021 by the authors. Licensee MDPI, Basel, Switzerland. This article is an open access article distributed under the terms and conditions of the Creative Commons Attribution (CC BY) license (https:// creativecommons.org/licenses/by/ $4.0 /)$.

\begin{abstract}
Adequate amounts of a wide range of micronutrients are needed by body tissues to maintain health. Dietary intake must be sufficient to meet these micronutrient requirements. Mineral deficiency does not seem to be the result of a physically active life or of athletic training but is more likely to arise from disturbances in the quality and quantity of ingested food. The lack of some minerals in the body appears to be symbolic of the modern era reflecting either the excessive intake of empty calories or a negative energy balance from drastic weight-loss diets. Several animal studies provide convincing evidence for an association between dietary micronutrient availability and microbial composition in the gut. However, the influence of human gut microbiota on the bioaccessibility and bioavailability of trace elements in human food has rarely been studied. Bacteria play a role by effecting mineral bioavailability and bioaccessibility, which are further increased through the fermentation of cereals and the soaking and germination of crops. Moreover, probiotics have a positive effect on iron, calcium, selenium, and zinc in relation to gut microbiome composition and metabolism. The current literature reveals the beneficial effects of bacteria on mineral bioaccessibility and bioavailability in supporting both the human gut microbiome and overall health. This review focuses on interactions between the gut microbiota and several minerals in sport nutrition, as related to a physically active lifestyle.
\end{abstract}

Keywords: micronutrient; trace element; physical fitness; gut microbiota; magnesium; Fe deficiency

\section{Introduction}

Physical activity, athletic training, or sport performance, depending on intensity, can increase the rate of energy turnover in skeletal muscle by up to 20-100 times that of the resting rate [1]. Therefore, higher energy and macronutrient intake is needed to meet the losses from energy expenditure, replenish glycogen stores, build muscles and repair tissues [2]. Suitable key recommendations and dietary strategies have been made with regard to energy and macronutrients for endurance athletes [3,4], game sports [5,6], strength and power sports [7,8], and track and field athletes [9].

For normal health to be maintained, a wide range of micronutrients such as vitamins, minerals, and trace elements must be present in sufficient amounts in body tissues, and dietary intake must be adequate to meet such needs [1]. However, the daily recommended need for micronutrients may not be related to the energy expenditure of physical activity [10]. Scientific data did not confirm higher micronutrient requirements in young athletes when compared to healthy controls [11]. Some researchers have determined that athletes require a higher intake of vitamins and minerals than their sedentary counterparts, whereas other researchers have reported no greater micronutrient requirements [12]. Exercise and athletic training involve the evaporation of perspiration from the skin with a sweat rate of more than $2 \mathrm{~L} / \mathrm{h}$ [13]. The concentration of sodium (Na), the main component of sweat, and the daily loss of Na because of athletic training vary according to sport intensity [14], 
gender [15], and intra/interindividual variability [16]. However, even with prolonged periods of heavy evaporation, overall sweat-induced deficiencies seem to be of minimal importance for trace minerals and vitamins [17]. Nevertheless, some micronutrient deficiencies might occur as a consequence of an inadequate and/or imbalanced diet with poor-quality food. Interestingly, excessive energy intake does not yet guarantee a sufficient daily recommended intake of micronutrients [18].

From the perspective of the gut microbiome, certain factors are of paramount importance, such as their bioavailability, food digestion, and absorption. Our aim here is to address this point and to provide up to date evidence for nutritionists, dieticians, sport medicine physicians, and individuals with a healthy lifestyle. In this narrative review, we discuss the interaction between gut microbiome and minerals (Table 1) and explain mechanism of their bioaccessibility and bioavailability related to the gut microbiome (Table 2). We focus on major essential minerals that are commonly accessible on the market as nutritional supplements, namely calcium $(\mathrm{Ca})$, magnesium $(\mathrm{Mg})$, iron $(\mathrm{Fe})$, zinc $(\mathrm{Zn})$, and selenium (Se) (Figure 1). Particular attention will be paid to fermentation, which is one of the oldest and most economical methods used in food preservation, as a possible means of attaining micronutrient requirements for athletic and health-related purposes. The extant literature has been searched using Scholar, PubMed, Web-of-Science, and Scopus from inception to March 2021 via database-adapted search strings based on the following key-words: micronutrient, gut microbiome, physical activity, athletes, fitness, and combinations thereof.

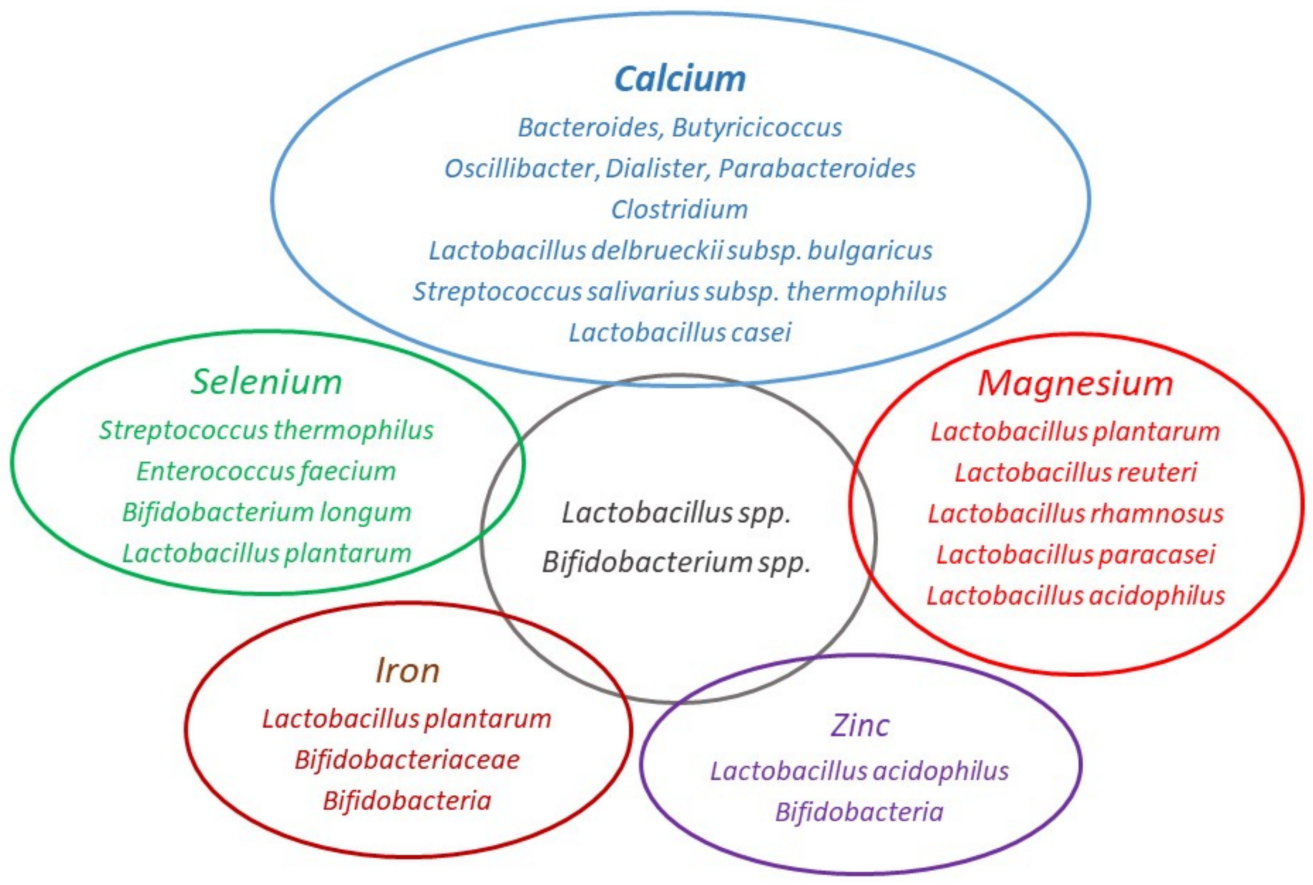

Figure 1. Bacterial strains related to mineral bioaccessibility and bioavailability. Image created according to Whisner et al. [19,20]; Amdekar et al. [21]; Aljewicz et al. [22]; Bergillos-Meca et al. [23]; Skrypnik and Suliburska [24]; Lidbeck et al. [25]; MassotCladera et al. [26]; Krausova et al. [27]; Malyar et al. [28] and Zhou et al. [29].

\section{Gut Microbiota, Mineral Availability, and Function}

\subsection{Calcium}

Calcium is the most abundant mineral in the human body, making up 1.5 to $2 \%$ of total body weight. Approximately $1200 \mathrm{~g}$ Ca is present in the body of an adult human, more than $99 \%$ of this amount being found in bones $[19,20]$. Ca is a key mineral for athletes, mainly because of its roles in maintaining bone health. Insufficient delivery of $\mathrm{Ca}$ to the body can cause bone loss and lead to risks of bone damage and injury [30] Muscle-skeletal structures respond positively to the weight-bearing and impact-loading aspects imposed 
by sport activity during childhood and adolescence [31]. The muscle strength of young athletes is associated with bone mineral density and content [32]. Further, strong evidence suggests that exercise benefits bone health at all ages and is a critical factor in osteoporosis prevention and treatment in both sexes [33]. However, female athletes under exhaustive training are particularly at risk of Ca deficiencies and of development of the female athlete triad, which refers to the interrelatedness of energy availability, menstrual function, and bone mineral density [34]. An omnivorous diet can provide adequate amounts of $\mathrm{Ca}$, especially when dairy products [milk, cheese, and yogurt], spinach, kale, okra, collards, soybeans, and white beans are consumed [35]. However, athletes commonly experience low energy availabilities that often result in reduced bone formation and strength and increased risk for stress fracture injuries [36]. To find the effect of instant low energy intake on bone metabolism in physically active human, Papageorgiou et al. [37] performed a randomized study with 5-day protocols of a controlled $\left(45 \mathrm{kcal} \cdot \mathrm{kgLBM}^{-1} \cdot \mathrm{d}^{-1}\right)$ and a restricted $\left[15 \mathrm{kcal} \cdot \mathrm{kgLBM}^{-1} \cdot \mathrm{d}^{-1}\right.$ ] diet. They concluded that five days of low energy availability decreased bone formation in both sexes and increased, but only in women, bone resorption.

Therefore, the absorption of $\mathrm{Ca}^{2+}$ in the intestine is essential for maintaining bone health and Ca homeostasis. Absorption occurs in transcellular and paracellular pathways [38]. The pivotal role for $\mathrm{Ca}^{2+}$ absorption (influx to enterocytes) in gastrointestinal tract play apically localized $\mathrm{Ca}^{2+}$-conducting channels TRPV6 (transient receptor potential vaniloid member 6), and perhaps to less extent also $\mathrm{Ca}^{2+}$-conducting channels TRPV5; and baso-laterally localized $\mathrm{Na}^{+} / \mathrm{Ca}^{2+}$ exchanger NCX1 and $\mathrm{Ca}^{2+}$ ATPase (PMCA1b), both responsible for $\mathrm{Ca}^{2+}$ efflux from enterocytes [39,40]. Knowledge of the molecular details of intestinal $\mathrm{Ca}^{2+}$ absorption might thus be essential for the prevention of osteoporosis and other pathologies related to $\mathrm{Ca}^{2+}$ metabolism and also for the development of nutritional and medical strategies [38]. The close relationship between cells of the immune system and bones explains the essential role of the intestinal microbiome in maintaining bone health and mineralization. Gut microbiota can increase $\mathrm{Ca}^{2+}$ absorption and modulate the production of gut serotonin, which is believed to interact with bone cells and to regulate bone metabolism [41].

\subsubsection{Effect of Prebiotics on Calcium Absorption}

The influence of gut microbiota on bone and the ways in which such effects are modulated by the diet are beginning to be explored. Several types of prebiotic plant fibers that reach the lower intestine result in an altered gut microbiome through the production of short-chain fatty acids. These changes positively associated with increases in fractional calcium absorption in adolescents and with increases in measurements of bone density and strength in animal models [42]. Whisner et al. [19] investigated the effect of soluble maize fiber on $\mathrm{Ca}^{2+}$ absorption and retention in pubertal children. A moderate daily intake of soluble maize fiber, a well-tolerated prebiotic, resulted in increased $\mathrm{Ca}^{2+}$ absorption during a 3-week period of metabolic balance testing in adolescents consuming less than the recommended amounts of $\mathrm{Ca}$ (diet contained $600 \mathrm{mg} \mathrm{Ca}$ ) [19]. When children consumed a soluble maize fiber, lower abundance of Firmicutes and higher abundance of Bacteroidetes were detected in the gut microbiota. Moreover, $\mathrm{Ca}^{2+}$ absorption was positively correlated with the genera Bacteroides, Butyricicoccus, Oscillibacter, and Dialister [19]. The same authors, in another study, proposed that the bacterial fermentation of soluble corn fiber to shortchain fatty acids (SCFA) reduced the gut luminal $\mathrm{pH}$, which increased $\mathrm{Ca}^{2+}$ solubility and transcellular absorption [20]. The proportion of the genus Parabacteroides significantly increased with soluble corn fiber dose. The authors suggested that two groups of bacteria were involved, namely the Bacteroidetes (Parabacteroides) fermenting soluble corn fiber to acetate or lactate, and the Firmicutes (Clostridium) further fermenting these substrates to butyrate, thereby promoting increased calcium absorption [20]. The production of SCFA increases acidity in the colon. This is thought to occur by direct SCFA acidification and by butyrate activation of $\mathrm{H}^{+} / \mathrm{Ca}^{2+}$ exchange. The lowered $\mathrm{pH}$ helps to increase 
mineral solubility making $\mathrm{Ca}^{2+}$ more absorbable $[43,44]$. On the other hand, Ca itself can provide a prebiotic effect. Ca-fed mice exhibit increased levels of Bifidobacterium spp. and Bacteroides to Prevotella [45]. Currently, there is very limited amount of inconclusive molecular data addressing possible role of microbiome in the regulation of transporters involved in transcellular $\mathrm{Ca}^{2+}$ absorption in intestine.

\subsubsection{Effect of Probiotics on Calcium Absorption}

Fermented dairy products (yogurts or soft cheese) have been used for thousands of years to preserve milk, extend shelf-life, and increase digestibility via lactose breakdown during fermentation. This processing of milk can be dated back to the sixth millennium BC when early agriculture began to appear in Northern Europe [46]. In humans, fermented dairy products are the primary source of probiotics [47]. Convincing evidence has been presented supporting the idea that probiotics, in dependence on the composition and metabolism of the gut microbiome, improve bone health by modulating both bone resorption by osteoclasts and bone formation by osteoblasts [48]. A few observational studies have confirmed positive associations between bone traits and the consumption of fermented milk products [49-51]. Even a short 2-week intervention [400 g/d] of the intake of fermented dairy products increases the abundance of Bifidobacterium species, Lactobacillus delbrueckii subsp. bulgaricus, and Streptococcus salivarius subsp. thermophilus [52]. Interestingly, increases in the density of lactic acid bacteria were no different following the consumption of fresh or pasteurized yogurt [53]. One possible mechanism for increasing $\mathrm{Ca}^{2+}$ availability is the higher absorption of $\mathrm{Ca}^{2+}$ in the intestine by probiotics and fermentation [54]. Gilman and Cashman [55] have previously reported that, in human intestinal-like Caco-2 cells in culture, Lactobacillus salivarius can increase $\mathrm{Ca}^{2+}$ uptake, although $\mathrm{Ca}^{2+}$ transport is unaffected by exposure of Caco-2 cells to probiotics [55].

The interplay between the immune and bone systems is known to be close, and chronic inflammatory conditions are associated with bone health [56]. The beneficial effect of probiotics on inflammatory conditions is well documented. The probiotic strain Lactobacillus casei inhibits pro-inflammatory cytokines TNF $\alpha$ and IL-6 and enhances anti-inflammatory cytokine IL-10 [21]. The quantity of gut pro-inflammatory bacteria is associated with the plasma levels of cytokines such as IL-6 and IL- 8 and, therefore, with systemic low-grade inflammation [57]. The way that probiotics impact human bone health is an area of intense research and is of interest to the general public. Probiotics in the form of yoghurt and other fermented food items might serve as easily accessible alternatives for a healthy diet and strong bones.

\subsection{Magnesium}

Magnesium (Mg) is the second most predominant cation within cells and is crucial both for the functions of a plethora of enzymes and for neuromuscular transmission [58]. It is a mandatory mineral that is involved in hundreds of biochemical reactions and physiological functions in the body. In addition to maintaining normal nerve and muscle function, heart rhythm, vasomotor tone, blood pressure, the immune system, bone integrity, and blood glucose levels, $\mathrm{Mg}^{2+}$ (ionized $\mathrm{Mg}$ ) antagonizes $\mathrm{Ca}^{2+}$ absorption, and thus $\left(\mathrm{Mg}^{2+}\right)$ influences $\mathrm{Ca}$ homeostasis [59]. When adjusted for energy, vitamin $\mathrm{D}, \mathrm{Ca}$, and phosphorus intake, $\mathrm{Mg}$ is a significant and strong predictor of bone mineral density [60]. However, numerous studies report a lower $\mathrm{Mg}$ intake among athletes in a variety of sports [61-65]. Exhaustive exercise apparently increases $\mathrm{Mg}$ losses via urine and sweat, possibly increasing its requirements by up to $20 \%$ [66]. A lower consumption of $\mathrm{Mg}$ can attenuate immunity to chronic inflammatory responses with consequences for the short- and long-term health and performance of athletes [59]. In Mg-deficient individuals, an increased dietary intake of $\mathrm{Mg}$ or supplementation might have beneficial effects on exercise performance. However, additional Mg supplementation has not been shown to improve physical performance in physically active individuals with an adequate $\mathrm{Mg}$ intake [66]. Similarly, as concluded in the meta-analysis and systematic review of Wang et al. [67], the current evidence does not 
support an advantageous effect of Mg supplementation on muscle fitness or on physically active individuals with an adequate or relatively high $\mathrm{Mg}$ status. Nevertheless, individuals with $\mathrm{Mg}$ deficiency might benefit from $\mathrm{Mg}^{2+}$ supplementation [67]. The main pathway of transcellular $\mathrm{Mg}^{2+}$ transport via enterocytes is constituted by the $\mathrm{Mg}^{2+}$-conducting chanzymes TRPM6/7, which mediate influx of $\mathrm{Mg}^{2+}$ into the cell and by the putative $\mathrm{Na}^{+} / \mathrm{Mg}^{2+}$ exchanger CNNM4 (cyclin and CBS domain divalent metal cation transport mediator 4) which is responsible for $\mathrm{Mg}^{2+}$ efflux [68-71]. According to profiles of protein expression, which are available in human protein atlas database (proteinatlas.org), also $\mathrm{Na}^{+} / \mathrm{Mg}^{2+}$ exchanger SLC41A1 (solute carrier family 41 member A1) is being abundantly expressed in gastro-intestinal tract. However, it is yet unknown, whether SLC41A1 plays as important role as CNNM4 in $\mathrm{Mg}^{2+}$ efflux in enterocytes, thus gut $\mathrm{Mg}^{2+}$ absorption [72].

Interaction between Magnesium and Intestinal Microbiota

Animal studies provide convincing evidence for an association between dietary $\mathrm{Mg}$ availability and microbial composition in the gut [73-75]. Jørgensen et al. [73] investigated the impact of dietary $\mathrm{Mg}$ deficiency on the composition of the gut microbiota in C57BL/ 6 mice. An Mg-deficient diet for 6 weeks altered the gut microbiota and was associated with altered anxiety-like behavior [73]. García-Legorreta et al. [76] studied the effect of low and high $\mathrm{Mg}$ diets on the modulation of the intestinal microbiota of male Wistar rats. Interestingly, after two weeks, the control and low $\mathrm{Mg}$ groups both had higher bacterial diversity than high $\mathrm{Mg}$ group. As the authors concluded for mice with no $\mathrm{Mg}$ deficiency, supplementation above recommended $\mathrm{Mg}$ intake levels can result in the development of intestinal dysbiosis. Hence, inadequate dietary $\mathrm{Mg}$ consumption may increase the capacity to harvest energy from the food [76].

Currently, little convincing evidence is available for an interaction between $\mathrm{Mg}$ deficiency and gut microbiota in humans. The combination of $\mathrm{Mg}^{2+}$ oxide with probiotics [Lactobacillus reuteri] appears to be promising for the treatment of chronic constipation in young patients. Interestingly, the administration of only Lactobacillus reuteri showed no significant decrease in stool consistency [77]. Magnesium also deserves attention in terms of bone density. Lambert et al. [78] studied postmenopausal osteopenic women supplemented with a combination of $\mathrm{Mg}$, $\mathrm{Ca}$, calcitriol, and bioavailable isoflavones and probiotics. Long-term consumption of minerals and probiotics for one year effectively affected bone metabolism and hormonal profile in estrogen deficient women. [78].

Intestinal bacteria may also play an important role in the bioavailability of $\mathrm{Mg}$. Aljewitz et al. [22] observed higher bioaccessibility of $\mathrm{Mg}$ and other minerals from cheese in combination with probiotics. Cultures of Lactobacillus spp. ingested with Dutch-type cheese increased the availability of $\mathrm{Mg}(\sim 18 \%)$ and $\mathrm{Ca}(\sim 2.5 \%)$ in vitro [22]. Similarly, fermented goats' milk containing Lactobacillus plantarum increased $\mathrm{Mg}$ bioavailability in comparison with commercial fermented goats' milks [23]. Probiotics also increase the bioavailability of minerals in vegetable milks. Fermentation of soy milk reduced the content of nutrients such as phytic acid, thereby increasing the bioavailability of $\mathrm{Mg}$ and other minerals [79].

The recommended $\mathrm{Mg}$ intake might positively affect the composition of the intestinal microbiota and, consequently, the metabolism of the host, thus helping to prevent metabolic alterations associated with the development of metabolic syndrome and type 2 diabetes [80]. However, to improve our understanding of the effects of dietary Mg content on the human gut microbiome, we need additional clinical trials.

\subsection{Iron}

$\mathrm{Fe}(\mathrm{Fe})$ is the most abundant trace metal in the human body [81] and has a number of functions. It is particularly important to athletes, since it is indispensable for oxygen transport and the processes involved in energy metabolism [82]. Although Fe regulation and storage is essential for athletic performance, endurance athletes often lack it. Fe deficiency is three times more common among women than men [82]. However, Fe deficiency and anemia associated with Fe deficiency are not related to sport only but 
are considered global health issues leading to the deterioration in the quality of life of patients and often to a serious prognosis in patients with chronic diseases. The origin of $\mathrm{Fe}$ deficiency and anemia is usually a combination of an increased loss of Fe and a decrease in its intestinal absorption and delivery from Fe stores because of inflammation [83].

Dietary iron is present in form of ferritin, heme and inorganic Fe [84]. Iron from ferritin is being absorbed with the protein by yet unknown mechanism and liberated as $\mathrm{Fe}^{2+}$ in lysosomes (Figure 2A) [85]. Heme iron is internalized by endocytosis (Figure 2A). HCP1 (haem carrier protein 1) is being likely involved in this process. Heme iron is released as $\mathrm{Fe}^{2+}$ in endosomes (Figure 2A) [85]. The Fe-regulated ferrireductase DCYTB (duodenal cytochrome b) is responsible for reduction of non-heme $\mathrm{Fe}^{3+}$ to $\mathrm{Fe}^{2+}$, which is then transported via DMT1 (divalent metal transporter 1) into enterocytes [86] (Figure 2A). Iron in form of $\mathrm{Fe}^{2+}$ is being effluxed from enterocytes via FPN1 (ferroportin 1 or SLC40A1) (Figure 2A). Until present, FPN1 is the only known $\mathrm{Fe}^{2+}$ extruder [87].

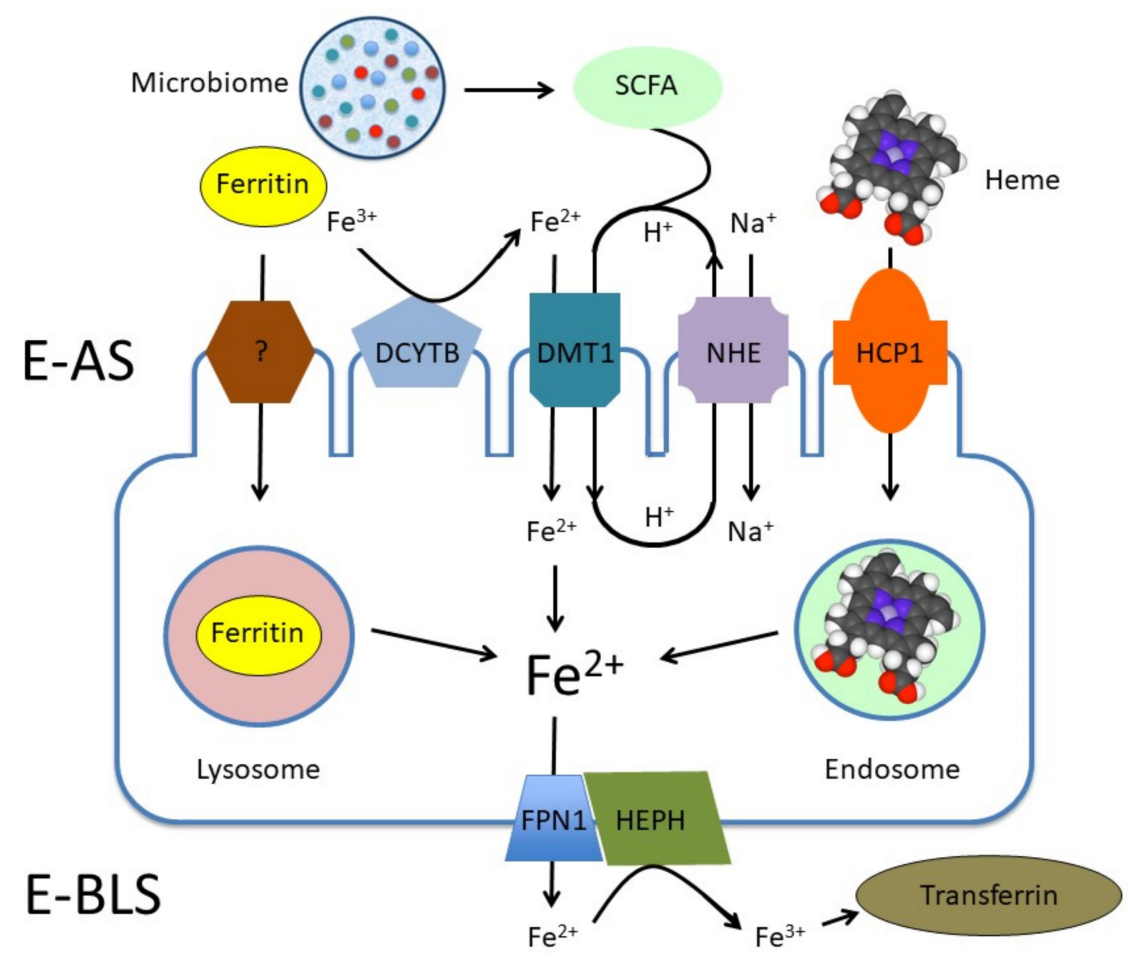

(A)

Figure 2. Cont. 


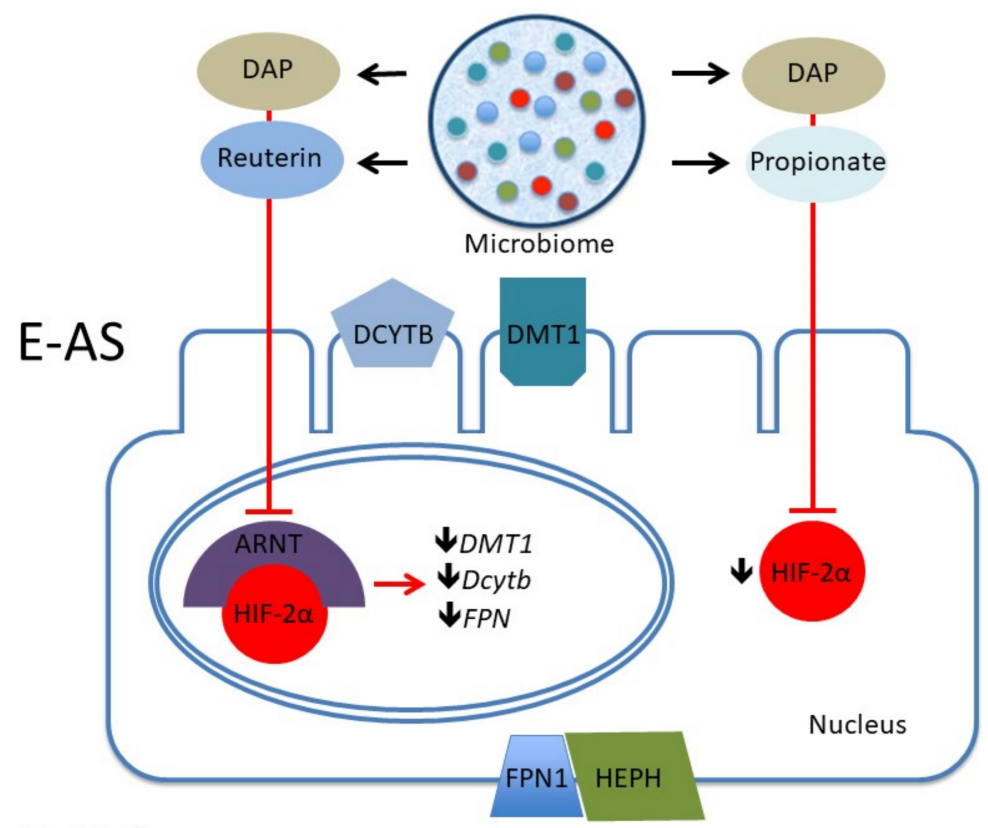

E-BLS

(B)

Figure 2. (A) Simplified model of iron transport via trans-cellular pathway in enterocytes. Dietary iron is absorbed on the apical side of enterocytes [E-AS] in form of ferritin, heme, or as $\mathrm{Fe}^{2+}$. A molecular background behind the uptake of ferritin by enterocytes is not yet clearly understood. Internalized ferritin undergoes degradation in lysosomes and $\mathrm{Fe}^{2+}$ is released. Endocytosis of heme is mediated by HCP1 (haem carrier protein 1). Heme is degraded in endosomes resulting in release of $\mathrm{Fe}^{2+}$. Nutritional iron has to be first reduced from $\mathrm{Fe}^{3+}$ to $\mathrm{Fe}^{2+}$ by ferrireductase DCYTB (duodenal cytochrome b) and it is uptaken as divalent cation by the enterocytes via DMT1 (divalent metal transporter 1), which operate in mode of $\mathrm{Fe}^{2+}: \mathrm{H}+$ symporter. Recycling of $\mathrm{H}^{+}$is maintained by NHE $\left(\mathrm{Na}^{+} / \mathrm{H}^{+}\right.$xchanger). SCFA (short chain fatty acids) produced by microbiota support the acidification on luminal side of the membrane. $\mathrm{Fe}^{2+}$ is exported from enterocytes on the basolateral side (E-BLS) by FPN1 (ferroportin 1). Released Fe2+ is oxidized by a transmembrane copperdependent ferroxidase HEPH [hephaestin] to $\mathrm{Fe} 3+$, which is utilized by transferrin in circulation. Figure 2A was modified from Gulec et al. [85]. (B) Involvement of microbial metabolite signaling in systemic Fe homeostasis. Microbial metabolites DAP (1,3-diaminopropane) and reuterin (3hydroxypropionaldehyde) inhibit ARNT (aryl hydro-carbon receptor nuclear translocator)-HIF- $2 \alpha$ (transcription factor) heterodimerization/translocation. This inhibition results in downregulation of expression of DMT1, DcytB and FPN genes, which encode for the key components of Fe homeostasis and $\mathrm{Fe}^{2+}$ transport in enterocytes. Moreover, microbial metabolites DAP and propionate inhibit HIF- $2 \alpha$ expression, thus influencing expression of Fe homeostatic factors/transporters.

Generally, supplementation in Fe-depleted patients optimizes and increases Fe absorption and might be a suitable therapeutic strategy [88]. Another approach is the fortification of cereals with ferrous and zinc sulfate as a strategy to prevent these deficiencies in the general population [89]. Nevertheless, "oral Fe is rife with unpleasant side-effects", including constipation, gastric irritation, nausea, and a metallic taste [90]. Consumption of Fe supplements increases $\mathrm{Fe}$ in the large intestine and consequently affects the composition of gut microbiota by reducing the amount of lactic acid bacteria (bifidobacteria and lactobacilli) and increasing the entropathogenic Escherichia coli, which is associated with intestinal inflammation [91]. In vivo and in vitro studies have reported adverse effects of oral $\mathrm{Fe}$ supplementation on the composition of gut microbiota, on the gut metabolome, and on intestinal health in patients with chronic kidney disease, which in turn might result in an increased production of uremic toxins [92]. Shifts in the composition of gut bacteria 
have been associated with oral Fe replacement therapy in inflammatory bowel disease patients [93]. Bifidobacteriaceae seem promising in this context, because they are capable of binding Fe in the large intestine and of reducing the risk of colorectal cancer by limiting the formation of free radicals associated with Fe [24,94]. The activity of bacterial enzymes involved in colon carcinogenesis might be elevated by a high-meat Western-type diet. Supplements of Lactobacillus acidophilus can decrease these levels in both rats and humans [25]. Balamurugan et al. [95] have investigated if the intestinal microbiota of young anemic women in India differs from non-anemic women. In anemic women they found lower abundance of fecal Lactobacilli. However, no further differences were significant to any of the other examined bacteria. Of note, similar intakes of energy, carbohydrate, fiber, $\mathrm{Fe}$, and milk were recorded in both groups [95].

Regarding previous, it is important to emphasize, that the molecular cross-talk between components of trans-cellular Fe absorption cascade and the microbiome is by far the best understood when compared to $\mathrm{Ca}, \mathrm{Mg}, \mathrm{Zn}$ and $\mathrm{Se}$. On one hand, similar to $\mathrm{Ca}, \mathrm{Mg}$, and perhaps also other cations, SCFA facilitate absorption of $\mathrm{Fe}^{2+}$ in gut (Figure 2A) $[84,96]$. On the other hand very exciting work identifying two microbial metabolites in intestine, namely DAP (1,3-diaminopropane) and reuterin (3-hydroxypropionaldehyde, an antimicrobial compound produced by Lactobacillus reuteri), which inhibits ARNT (aryl hydro-carbon receptor nuclear translocator)-HIF- $2 \alpha$ heterodimerization/translocation, thus downregulate expression of key components of iron transporst in enterocytes, DMT1, DcytB and FPN has been published recently by the group around Das et al. [97] (Figure 2B). Furthermore, the same group identified DAP and propionate as microbial metabolites capable of inhibiting HIF- $2 \alpha$ expression (Figure 2B). Thus, Das and colleagues provided a direct evidence for involvement of microbial metabolite signaling in systemic Fe homeostasis.

\section{Fermentation and Iron Bioavailability}

Increasing the absorption of Fe from naturally occurring and unprocessed food may serve as an alternative to dietary supplements. The fermentation of cereals provides optimum $\mathrm{pH}$ conditions for the enzyme degradation of phytate, presented in the form of complexes with proteins and polyvalent cations such as zinc, calcium, magnesium, and Fe [98]. Phytate reduction might increase the levels of soluble and bioavailable minerals including Fe [99].

Another means of increasing the bioavailability of Fe is the soaking and germination of certain crops [100]. From this perspective, the plant microbiome, which includes the microbial community that typically interacts extensively with the plant, is of interest. The plant microbiome survives either inside or outside of plant tissues, performs numerous plant-beneficial activities, and promotes plant growth [101]. Teng et al. [102] have demonstrated that plant-derived exosome-like nanoparticles are taken up by the gut microbiota of animals and contain RNAs that alter microbiome composition and host physiology. Further research is urgently required if we are to understand the association between plant and human gut microbiomes and the mechanisms by which food products modulate commensals, a topic that remains basically unexplained. To better understand the effect of human intestinal microbiota on the bioavailability of Fe from plant foods, further research is needed. Cai et al. [103] suggest that human gut microbiota might increase the extraction of Fe from vegetables. They have recently shown, although only in vitro, that the bioaccessibility of Fe in the colon phase is probably significantly higher [1.3-1.8 times] than that in the small intestinal phase [103].

Dietary iron exists in two forms: heme iron $\left(\mathrm{Fe}^{2+}\right)$ and non-heme iron $\left(\mathrm{Fe}^{3+}\right)$ with transformation between these two states [104]. $\mathrm{Fe}^{3+}$ has to be reduced to the $\mathrm{Fe}^{2+}$ by a ferrireductase duodenal cytochrome before its uptake in the small intestine by the divalent metal transporter 1, which only transports $\mathrm{Fe}^{2+}$ [105]. In the anaerobic environment of the colon, $\mathrm{Fe}^{3+}$ can be easily reduced to $\mathrm{Fe}^{2+}$, leading to reductive dissolution of the $\mathrm{Fe}^{3+}$ compound [106]. Since $\mathrm{Fe}^{3+}$ is insoluble in most natural environments, many microbes rely on high-affinity $\mathrm{Fe}^{3+}$ siderophores for $\mathrm{Fe}^{3+}$ assimilation [107]. Luu and Ramsay [107] 
have proposed three mechanisms for the removal of iron from the siderophore: (a) the iron-siderophore complex is transported across the cell membrane, and the metal is released intracellularly because of low siderophore affinity for $\mathrm{Fe}^{2+}$; (b) the iron-siderophore complex is taken up into the cell, and iron is released through the destruction or chemical modification of the ligand; [c] the siderophore acts as an iron shuttle, but the iron does not enter the cell being instead donated to a second membrane-bound chelator followed by reduction, with the siderophore remaining outside cell [107].

When Fe supplementation is undertaken, the use of prebiotics and probiotics to mitigate the side effects of Fe on the gut should be taken in to account [93]. Probiotics seem to be effective with regard to Fe absorption in humans, as reported in the systematic review and meta-analysis of Vonderheid et al. [108]. They have found that the probiotic Lactobacillus plantarum $299 v$ significantly increases non-heme dietary Fe absorption during a specific test period in crossover-designed studies compared with a control period [108].

\subsection{Zinc}

After iron, zinc [Zn] is the second most abundant trace element in the human body [81], with the majority of it occurring in skeletal muscles and bones [109]. However, dietary intake is required to prevent $\mathrm{Zn}$ deficiency, as the human body does not have a tissue depot for $\mathrm{Zn}$ [109]. $\mathrm{Zn}$ is an essential trace metal with crucial roles in growth, development, and the maintenance of immune function [110], plus catalytic, structural, and signaling functions affecting many cellular processes [109]. Zn deficiency has been associated with the immune response, cell proliferation, and pathogenesis and with the pathophysiology of selected diseases such as depression, bone disease, cardiovascular diseases, diabetes mellitus, Alzheimer's disease, and Wilson's disease [111,112]. Zn deficiency is relatively common in the physically active and in athletes [113]. In physically active individuals, $\mathrm{Zn}$ deficiency can lead to eating disorders characterized by weight loss, latent fatigue with decreased endurance capacity, and the risk of osteoporosis [114].

The nutritional habits that are often adopted in an attempt to enhance endurance performance, namely an excessive increase in carbohydrates and low intake of proteins and fat, can lead to inadequate $\mathrm{Zn}$ intake in $90 \%$ of athletes [114]. As concluded by Baranauskas et al. [115], particular attention should be focused on female athletes. These researchers evaluated the consumption of vitamins and minerals based on the dietary habits of 38 highly trained women. Barely one third consumed less $\mathrm{Zn}$ than the recommended daily intake [115]. A further group of higher risk individuals are those with low calorie intakes; they should consume foods with high micronutrient contents [116]. Special attention also needs to be paid to adult vegans and to physically active individuals [117]. In order to cover their daily recommended intake of $\mathrm{Zn}$, athletes have to consume a wellbalanced diet including supplements or fortified products [118]. However, no real benefit ensues from supplementation unless the athletes are $\mathrm{Zn}$-deficient [113]. Consumption of Zn supplements has a limited, if any, effect on sports performance. [119]. The positive effects of $\mathrm{Zn}$ supplementation on the pathogenesis of COVID-19 are still questionable. $\mathrm{Zn}$ deficiency is possibly one of the factors predisposing individuals to infection and severe COVID-19, due to the fact that $\mathrm{Zn}$ is essential for the protection of natural tissue barriers such as respiratory epithelium [120]. Patients with severe COVID-19 are frequently also diagnosed as being $\mathrm{Zn}$-deficient. This might result from modern dietary habits, which are often accompanied by Zn deficiency [121].

\section{Association between Zinc and Gut Microbiota}

Unlike iron, zinc is a divalent cation and does not require a redox reaction during the membrane transport process [122]. From more than twenty Zn transporters, Irt-related protein 4 is essential for the uptake of dietary zinc at the apical membrane in intestinal epithelial cells, and thus, the SLC39A4 gene mutation is associated with zinc deficiency and results in a rare inherited recessive disease (Acrodermatitis enteropathica) $[123,124]$. The $\mathrm{Zn}^{2+}$ efflux from enterocytes is secured by ZnT1 transporter (also known as SLC30A1), 
which may operate as $\mathrm{Zn}^{2+} / \mathrm{H}^{+}$exchanger [125]. However, an insufficient dietary intake of $\mathrm{Zn}$ suggests the role of gut microbiota in this function, with the composition of the gut microbiota possibly affecting $\mathrm{Zn}$ absorption [126]. In vitro studies have indicated that the bioaccessibility of $\mathrm{Zn}$ from vegetables is mainly influenced by the microbiota of the colon $[103,127]$. However, the lower impact of the human gut microbiota on the bioaccessibility and bioavailability of elemental $\mathrm{Zn}$ from vegetables might be attributable to the bioaccessibility of $\mathrm{Zn}$ being higher in the small intestinal phase [103]. This is in accordance with the study of Intawongse and Dean [128] who have found that most of the metals coming from a wide range of vegetables are dissolved in the gastric and intestinal phases. Thus, gut microbiota might significantly affect the bioaccessibility of Zn contained in vegetables, as they reduce the dissolution of $\mathrm{Zn}$ in the colon phase. [103]. Based on the bioavailability of $\mathrm{Zn}$, the best vegetable sources has been found to be lettuce. However, the consumption of $300 \mathrm{~g}$ of lettuce only meets $2.7 \%$ and $4.5 \%$ of $\mathrm{Zn}$ daily demands by males and females, respectively [103]. Currently, limited evidence coming mostly from animal studies has associated $\mathrm{Zn}$ with the gut microbiota [129-131]. Zn-deficient chicks have a significantly lower bacterial richness and $\alpha$-diversity when measured on the Chao1 Index [130]. Zn deficiency in mice can negatively alter microbiota composition and function and gut-brain signaling and can trigger an increase of inflammatory markers [131].

Any $\mathrm{Zn}$ or Fe not absorbed in the small intestine of the healthy human reaches the colon and is available to colonocytes and/or commensal bacteria. Commensal bacteria probably increase the bioavailability of $\mathrm{Zn}$ and Fe and provide them to the host [132]. Under conditions of inflammation, pathogens outcompete commensal bacteria for these metals, thereby reducing Fe and $\mathrm{Zn}$ levels [132]. The consumption of Acacia, a prebiotic fiber, has been associated with a higher presence of Lactobacillus and Bifidobacterium spp in the gut and higher $\mathrm{Zn}$ concentrations in the femur of Wistar rats [26]. Four weeks after the consumption of gum arabic (a dried exudate of the acacia tree), the amount of Bifidobacteria and Lactobacilli was shown to increase in human stool samples, although $\mathrm{Zn}$ was not examined [133]. In another animal model, under heat stress conditions, zinc-enriched probiotics supplementation improved immune function by increasing serum IL-2, IL-6, and IFN- $\gamma$ and decreasing IL-10 [28]. Contrary to benefits of Zn supplementation in deficient subjects, excessive dietary $\mathrm{Zn}$ in a mouse model altered the gut microbiota and decreased resistance to $C$. difficile infection [134].

Table 1. Interaction between gut microbiome and minerals.

\begin{tabular}{|c|c|c|c|}
\hline Intervention & Study Population & Main Outcome & References \\
\hline Soluble maize fiber & $\begin{array}{l}24 \text { adolescent children } \\
\text { (12-15 years })\end{array}$ & $\begin{array}{c}\text { Fractional } \mathrm{Ca}^{2+} \text { absorption } \\
\text { was } 12 \% \text { higher after } \\
\text { treatment. Phylum } \\
\text { Bacteroidetes was } \\
\text { significantly greater }\end{array}$ & Whissner et al. [19] \\
\hline $\mathrm{Mg}^{2+}$ oxide & $\begin{array}{l}60 \text { young children with } \\
\text { functional constipation } \\
\text { ( }>6 \text { month to }<6 \text { years) }\end{array}$ & $\begin{array}{c}\text { Decrease in stool consistency } \\
\text { and suppressed presence of } \\
\text { the genus Dialister }\end{array}$ & Kubota et al. [77] \\
\hline Iron sulfate & 53 patients with IBD & $\begin{array}{l}\text { Decreased abundances of } \\
\text { Ruminococcus bromii, Dorea sp., } \\
\text { Faecalibacterium prausnitzii and } \\
\text { Collinsella aerofaciens }\end{array}$ & Lee at a. [93] \\
\hline Zn-biofortified wheat diet & Animal model (Gallus gallus) & $\begin{array}{l}\text { Increased } \beta \text {-microbial } \\
\text { diversity and increased } \\
\text { Zn-dependent bacterial } \\
\text { metabolic pathways }\end{array}$ & Reed at al. [129] \\
\hline $\begin{array}{l}\text { Se- and Zn-enriched } \\
\text { Lactobacillus plantarum }\end{array}$ & Animal model (Mus musculus) & $\begin{array}{l}\text { Increased antioxidant activity } \\
\text { and blood Se level }\end{array}$ & Kang et al. [135] \\
\hline
\end{tabular}




\subsection{Selenium}

Selenium (Se) is an essential mineral in humans as it has antioxidant, anti-inflammatory, and immune functions, it participates in the metabolism of thyroid hormones, and it acts a cofactor of several selenoproteins [136,137]. Wardenaar et al. [138] examined whether high-level athletes followed the recommendations on micronutrients and whether their adequacy is linked to the use of nutritional and sports supplements. As expected, they found lower levels of Se in 10\% of non-users [138]. One risk factor in deficiencies in Se might be veganism $[139,140]$. On the contrary, low-carbohydrate ketogenic diets preferably consumed by athletes for body composition benefits increase Se intake because of the nature of the consumed animal food [141]. However, supplementation with additional Se seems to provide limited beneficial effects on aerobic or anaerobic performance [142-145]. However, the association between Se levels and the risk of death from COVID-19 is noteworthy $[146,147]$. Se supplementation seems to have no effects on the athletic performance of physically active individuals with an adequate Se intake.

\section{Interaction of Selenium and Probiotics}

The gastrointestinal microbiota has been shown to affect Se status and selenoprotein expression in mice [148] and is able to sequester Se and to restrict its availability to the host [149]. Bacteria may compete with the host for Se when availability becomes limiting [148], although, in the mouse model, Lactobacillus plantarum enriched with Se and Zn increases antioxidant activity and blood Se levels [135]. In the study of Krausova et al. [27], the administration of Se-enriched lactic acid bacteria (Streptococcus thermophilus and Enterococcus faecium) improved the antioxidant status of the rats.

Food sources contain various chemical forms of bioselenocompounds, which might be transformed to selenomethionine [SeMet] by the gut microflora of a host, thereby allowing it to receive this essential micronutrient [150]. Takahashi et al. [150] suggest that SeMet is transported into bacterial cells; one part is incorporated into bacterial proteins, and the other part is excreted into the medium. SeMet-containing proteins are then available as a Se pool for the host [150]. Selenium-enriched Bifidobacterium longum from human stools efficiently biotransforms inorganic $\mathrm{Se}\left[\mathrm{Na}_{2} \mathrm{SeO}_{3}\right]$ into more bioactive organic Se forms (e.g., SeMet) [151]. In a study by Wastney et al. [152] the enteric absorption of single doses of SeMet by healthy subjects was $98 \%$, indicating the high bioaccessibility of SeMet. Moreover, another investigation demonstrated that the bacterial selenized forms selenocystein (SeCys) and SeMet were also present in the liver and kidney tissues of rats after 58 days under an experimental diet [27]. In a further study, the Se content in the liver of animals fed a diet fortified with Se-enriched Bifidobacterium longum was much higher than that of animals fed a selenite-enriched diet [29]. Se- and Zn-enriched probiotics might thus be applied as promising functional food ingredients in the future [135]. Probiotics enriched with Se and Zn possibly increase bioavailability and absorption when compared with their inorganic forms, thus opening up another application for probiotics [153].

Beneficial effects of bacteria on absorbtion, bioaccessibility and bioavailability of all five discussed mineral are summarized in Table 2. 
Table 2. The absorption, bioaccessibility, and bioavailability of essential minerals in relation to the gut microbiome.

\begin{tabular}{|c|c|c|c|}
\hline Prebiotic/Probiotics & Mechanisms & Main Outcome & References \\
\hline $\begin{array}{l}\text { Lactobacillus salivarius and } \\
\text { Bifidobacterium infantis }\end{array}$ & $\begin{array}{l}\text { Transepithelial calcium } \\
\text { transport }\end{array}$ & $\begin{array}{l}\text { Enhanced intestinal calcium } \\
\text { uptake }\end{array}$ & Gilman and Cashman [55] \\
\hline $\begin{array}{l}\text { Se-enriched Bifidobacterium } \\
\text { longum }\end{array}$ & $\begin{array}{l}\text { Biotransformation of } \\
\text { inorganic Se into bioactive } \\
\text { organic Se }\end{array}$ & $\begin{array}{l}\text { High bioaccessibility of } \\
\text { selenomethionine and } 98 \% \\
\text { enteric absorbtion }\end{array}$ & $\begin{array}{c}\text { Zhu et al. [151]; Wastney et al. } \\
\text { [152] }\end{array}$ \\
\hline Prebiotic fiber Acacia & $\begin{array}{l}\text { Increased Lactobacillus and } \\
\text { Bifidobacterium spp in the gut }\end{array}$ & $\begin{array}{l}\text { Higher } \mathrm{Zn} \text { concentrations in } \\
\text { the femur of Wistar rats }\end{array}$ & Massot-Cladera et al. [26] \\
\hline Lactobacillus plantarum & $\begin{array}{l}\text { Microbial metabolite } \\
\text { production, enhanced mucin } \\
\text { production and } \\
\text { immunomodulation }\end{array}$ & $\begin{array}{l}\text { Increased non-heme dietary } \\
\text { Fe absorption }\end{array}$ & Vonderheid et al. [26] \\
\hline $\begin{array}{c}\text { Soluble corn fiber, } \\
\text { Parabacteroides and Clostridium }\end{array}$ & $\begin{array}{l}\text { Acidification and SCFA } \\
\text { production }\end{array}$ & $\begin{array}{l}\text { Increased mineral solubility } \\
\text { and calcium absorption }\end{array}$ & $\begin{array}{c}\text { Trinidad et al. [26]; Cashman } \\
\text { [44] }\end{array}$ \\
\hline $\begin{array}{l}\text { Fermented soymilk with } \\
\text { various lactic acid bacteria }\end{array}$ & $\begin{array}{l}\text { Reducing the content of } \\
\text { phytic acid }\end{array}$ & $\begin{array}{l}\text { Increasing the bioavailability } \\
\text { of magnesium, calcium, iron } \\
\text { and zinc }\end{array}$ & Rekha and Vijayalakshmi [79] \\
\hline $\begin{array}{l}\text { Fermented goats' milks with } \\
\text { Lactobacillus plantarum }\end{array}$ & Not totally clear & $\begin{array}{l}\text { Increased magnesium and } \\
\text { calcium bioavailability }\end{array}$ & Bergillos-Meca et al. [23] \\
\hline
\end{tabular}

\section{Conclusions}

The available literature indicates the beneficial effects of bacteria on mineral bioaccessibility and bioavailability and hence on their support of animal and human gut microbiomes and host vitality. The positive effect of probiotics on mineral absorption is promising in relation to the composition and metabolism of the gut microbiome. The fermentation of cereals and the soaking and germination of crops have the potential of providing suitable natural mineral supplements that can sustain both the human gut microbiome and overall health. Fermented foods and beverages might be helpful in increasing the levels of soluble and bioavailable micronutrients and might act as "nutrition supplements". However, more research is needed if we are to improve our understanding of the role of microbiota in micronutrient metabolism and mechanisms related to the bioaccessibility and bioavailability of minerals in human gut.

Author Contributions: Conceptualisation, V.B. and M.K.; Writing—original draft preparation, V.B.; Writing-review and editing, M.K.; Visualisation, M.K. and V.B.; Supervision, M.K.; Funding acquisition, V.B. All authors have read and agreed to the published version of the manuscript.

Funding: This review was funded by the granting schemes APVV-17-0099 and VEGA 1/0260/21.

Institutional Review Board Statement: Not applicable.

Informed Consent Statement: Not applicable.

Data Availability Statement: Not applicable.

Acknowledgments: We thank to Theresa Jones for the language editing of the manuscript. We also thank Andrea Motloch Audy for the drawings in the graphical abstract.

Conflicts of Interest: The authors declare no conflict of interest.

\section{References}

1. Maughan, R.J. Role of micronutrients in sport and physical activity. Br. Med. Bull. 1999, 55, 683-690. [CrossRef]

2. Rodriguez, N.R.; Di Marco, N.M.; Langley, S. American College of Sports Medicine position stand. Nutrition and athletic performance. Med. Sci. Sports Exerc. 2009, 41, 709-731. [PubMed]

3. Vitale, K.; Getzin, A. Nutrition and Supplement Update for the Endurance Athlete: Review and Recommendations. Nutrients 2019, 11, 1289. [CrossRef] [PubMed] 
4. Casazza, G.A.; Tovar, A.P.; Richardson, C.E.; Cortez, A.N.; Davis, B.A. Energy Availability, Macronutrient Intake, and Nutritional Supplementation for Improving Exercise Performance in Endurance Athletes. Curr. Sports Med. Rep. 2018, 17, 215-223. [CrossRef] [PubMed]

5. Steffl, M.; Kinkorová, I.; Kokstejn, J.; Petr, M. Macronutrient Intake in Soccer Players-A Meta-Analysis. Nutrients 2019, 11, 1305. [CrossRef]

6. Black, K.E.; Black, A.D.; Baker, D.F. Macronutrient Intakes of Male Rugby Union Players: A Review. Int. J. Sport Nutr. Exerc. Metab. 2018, 28, 664-673. [CrossRef] [PubMed]

7. Storey, A.; Smith, H.K. Unique aspects of competitive weightlifting: Performance, training and physiology. Sports Med. 2012, 42, 769-790. [CrossRef]

8. Slater, G.J.; Sygo, J.; Jorgensen, M. SPRINTING ... Dietary Approaches to Optimize Training Adaptation and Performance. Int. J. Sport Nutr. Exerc. Metab. 2019, 29, 85-94. [CrossRef]

9. Close, G.L.; Sale, C.; Baar, K.; Bermon, S. Nutrition for the Prevention and Treatment of Injuries in Track and Field Athletes. Int. J. Sport Nutr. Exerc. Metab. 2019, 29, 189-197. [CrossRef]

10. Heydenreich, J.; Melzer, K.; Flury, C.; Kayser, B. Low Energy Turnover of Physically Inactive Participants as a Determinant of Insufficient Mineral and Vitamin Intake in NHANES. Nutrients 2017, 9, 754. [CrossRef]

11. Hannon, M.P.; Flueck, J.L.; Gremeaux, V.; Place, N.; Kayser, B.; Donnelly, C. Key Nutritional Considerations for Youth Winter Sports Athletes to Optimize Growth, Maturation and Sporting Development. Front. Sports Act. Living 2021, 3. [CrossRef]

12. Volpe, S.L. Micronutrient Requirements for Athletes. Clin. Sports Med. 2007, 26, 119-130. [CrossRef]

13. Maughan, R.J.; Noakes, T.D. Fluid replacement and exercise stress. A brief review of studies on fluid replacement and some guidelines for the athlete. Sports Med. 1991, 12, 16-31. [CrossRef]

14. Baker, L.B.; De Chavez, P.J.D.; Ungaro, C.T.; Sopeña, B.C.; Nuccio, R.P.; Reimel, A.J.; Barnes, K.A. Exercise intensity effects on total sweat electrolyte losses and regional vs. whole-body sweat $[\mathrm{Na}+],[\mathrm{Cl}-]$, and $[\mathrm{K}+]$. Graefe's Arch. Clin. Exp. Ophthalmol. 2019, 119, 361-375. [CrossRef] [PubMed]

15. Baker, L.B. Sweating Rate and Sweat Sodium Concentration in Athletes: A Review of Methodology and Intra/Interindividual Variability. Sports Med. 2017, 47, 111-128. [CrossRef] [PubMed]

16. Godek, S.F.; Peduzzi, C.; Burkholder, R.; Condon, S.; Dorshimer, G.; Bartolozzi, A.R. Sweat Rates, Sweat Sodium Concentrations, and Sodium Losses in 3 Groups of Professional Football Players. J. Athl. Train. 2010, 45, 364-371. [CrossRef] [PubMed]

17. Baker, L.B. Physiology of sweat gland function: The roles of sweating and sweat composition in human health. Temperature 2019, 6, 211-259. [CrossRef]

18. Kimmons, J.E.; Blanck, H.M.; Tohill, B.C.; Zhang, J.; Khan, L.K. Associations Between Body Mass Index and the Prevalence of Low Micronutrient Levels Among US Adults. MedGenMed Medscape Gen. Med. 2006, 8, 59. [PubMed]

19. Whisner, C.M.; Martin, B.R.; Nakatsu, C.H.; McCabe, G.P.; McCabe, L.D.; Peacock, M.; Weaver, C.M. Soluble maize fibre affects short-term calcium absorption in adolescent boys and girls: A randomised controlled trial using dual stable isotopic tracers. Br. J. Nutr. 2014, 112, 446-456. [CrossRef] [PubMed]

20. Whisner, C.M.; Martin, B.R.; Nakatsu, C.H.; A Story, J.; Macdonald-Clarke, C.J.; McCabe, L.D.; McCabe, G.P.; Weaver, C.M. Soluble Corn Fiber Increases Calcium Absorption Associated with Shifts in the Gut Microbiome: A Randomized Dose-Response Trial in Free-Living Pubertal Females. J. Nutr. 2016, 146, 1298-1306. [CrossRef]

21. Amdekar, S.; Singh, V.; Singh, R.; Sharma, P.; Keshav, P.; Kumar, A. Lactobacillus casei reduces the inflammatory joint damage associated with collagen-induced arthritis (CIA) by reducing the pro-inflammatory cytokines: Lactobacillus casei: COX-2 inhibitor. J. Clin. Immunol. 2011, 31, 147-154. [CrossRef] [PubMed]

22. Aljewicz, M.; Siemianowska, E.; Cichosz, G.; Tońska, E. The effect of probiotics (Lactobacillus rhamnosus HN001, Lactobacillus paracasei LPC-37, and Lactobacillus acidophilus NCFM) on the availability of minerals from Dutch-type cheese. J. Dairy Sci. 2014, 97, 4824-4831. [CrossRef]

23. Bergillos-Meca, T.; Cabrera-Vique, C.; Artacho, R.; Moreno-Montoro, M.; Navarro-Alarcón, M.; Olalla, M.; Giménez, R.; Seiquer, I.; Ruiz-López, M.D. Does Lactobacillus plantarum or ultrafiltration process improve $\mathrm{Ca}, \mathrm{Mg}, \mathrm{Zn}$ and $\mathrm{P}$ bioavailability from fermented goats' milk? Food Chem. 2015, 187, 314-321. [CrossRef]

24. Skrypnik, K.; Suliburska, J. Association between the gut microbiota and mineral metabolism. J. Sci. Food Agric. 2018, 98, 2449-2460. [CrossRef] [PubMed]

25. Lidbeck, A.; E Nord, C.; Gustafsson, J.-A.; Rafter, J. Lactobacilli, anticarcinogenic activities and human intestinal microflora. Eur. J. Cancer Prev. 1992, 1, 341-354. [CrossRef] [PubMed]

26. Massot-Cladera, M.; Azagra-Boronat, I.; Franch, À.; Castell, M.; Rodríguez-Lagunas, M.J.; Pérez-Cano, F.J. Gut Health-Promoting Benefits of a Dietary Supplement of Vitamins with Inulin and Acacia Fibers in Rats. Nutrients 2020, 12, 2196. [CrossRef] [PubMed]

27. Krausova, G.; Kana, A.; Vecka, M.; Hyrslova, I.; Stankova, B.; Kantorova, V.; Mrvikova, I.; Huttl, M.; Malinska, H. In Vivo Bioavailability of Selenium in Selenium-Enriched Streptococcus thermophilus and Enterococcus faecium in CD IGS Rats. Antioxidants 2021, 10, 463. [CrossRef]

28. Malyar, R.M.; Li, H.; Enayatullah, H.; Hou, L.; Farid, R.A.; Liu, D. Zinc-enriched probiotics enhanced growth performance, antioxidant status, immune function, gene expression, and morphological characteristics of Wistar rats raised under high ambient temperature. 3 Biotech. 2019, 9, 291. [CrossRef] 
29. Zhou, Y.; Zhu, H.; Qi, Y.; Wu, C.; Zhang, J.; Shao, L.; Tan, J.; Chen, D. Absorption and Distribution of Selenium Following Oral Administration of Selenium-Enriched Bifidobacterium longum DD98, Selenized Yeast, or Sodium Selenite in Rats. Biol. Trace Element Res. 2019, 197, 599-605. [CrossRef] [PubMed]

30. Dobrowolski, H.; Karczemna, A.; Włodarek, D. Nutrition for Female Soccer Players-Recommendations. Medicina 2020, 56, 28. [CrossRef]

31. Lozano-Berges, G.; Matute-Llorente, Á.; González-Agüero, A.; Gómez-Bruton, A.; Gómez-Cabello, A.; Vicente-Rodríguez, G.; Casajús, J.A. Soccer helps build strong bones during growth: A systematic review and meta-analysis. Eur. J. Nucl. Med. Mol. Imaging 2017, 177, 295-310. [CrossRef] [PubMed]

32. Seabra, A.; Marques, E.; Brito, J.; Krustrup, P.; Abreu, S.; Oliveira, J.; Rego, C.; Mota, J.; Rebelo, A. Muscle strength and soccer practice as major determinants of bone mineral density in adolescents. Jt. Bone Spine 2012, 79, 403-408. [CrossRef]

33. Goolsby, M.A.; Boniquit, N. Bone Health in Athletes. Sports Health Multidiscip. Approach 2017, 9, 108-117. [CrossRef] [PubMed]

34. Thein-Nissenbaum, J.; Hammer, E. Treatment strategies for the female athlete triad in the adolescent athlete: Current perspectives. Open Access J. Sports Med. 2017, 8, 85-95. [CrossRef]

35. Sale, C.; Elliott-Sale, K.J. Nutrition and Athlete Bone Health. Sports Med. 2019, 49, 139-151. [CrossRef] [PubMed]

36. Papageorgiou, M.; Dolan, E.; Elliott-Sale, K.J.; Sale, C. Reduced energy availability: Implications for bone health in physically active populations. Eur. J. Nutr. 2018, 57, 847-859. [CrossRef] [PubMed]

37. Papageorgiou, M.; Elliott-Sale, K.J.; Parsons, A.; Tang, J.C.; Greeves, J.P.; Fraser, W.D.; Sale, C. Effects of reduced energy availability on bone metabolism in women and men. Bone 2017, 105, 191-199. [CrossRef]

38. Diaz de Barboza, G.; Guizzardi, S.; Tolosa de Talamoni, N. Molecular aspects of intestinal calcium absorption. World J. Gastroenterol. 2015, 21, 7142-7154. [CrossRef]

39. Peng, J.-B.; Suzuki, Y.; Gyimesi, G.; Hediger, M.; Kozak, J.A.; Putney, J.W. TRPV5 and TRPV6 Calcium-Selective Channels. In Calcium Entry Channels in Non-Excitable Cells; Informa UK Limited: London, UK, 2017; pp. 241-274.

40. Liao, Q.-S.; Du, Q.; Lou, J.; Xu, J.-Y.; Xie, R. Roles of Na+/Ca2+ exchanger 1 in digestive system physiology and pathophysiology. World J. Gastroenterol. 2019, 25, 287-299. [CrossRef]

41. D'Amelio, P.; Sassi, F. Gut Microbiota, Immune System, and Bone. Calcif. Tissue Int. 2018, 102, 415-425. [CrossRef]

42. Weaver, C.M. Diet, Gut Microbiome, and Bone Health. Curr. Osteoporos. Rep. 2015, 13, 125-130. [CrossRef] [PubMed]

43. Trinidad, T.P.; Wolever, T.M.; Thompson, L.U. Effect of acetate and propionate on calcium absorption from the rectum and distal colon of humans. Am. J. Clin. Nutr. 1996, 63, 574-578. [CrossRef]

44. Cashman, K. Prebiotics and calcium bioavailability. Curr. Issues Intest. Microbiol. 2003, 4, 21-32. [PubMed]

45. Chaplin, A.; Parra, P.; Laraichi, S.; Serra, F.; Palou, A. Calcium supplementation modulates gut microbiota in a prebiotic manner in dietary obese mice. Mol. Nutr. Food Res. 2015, 60, 468-480. [CrossRef]

46. Salque, M.; Bogucki, P.I.; Pyzel, J.; Sobkowiak-Tabaka, I.; Grygiel, R.; Szmyt, M.; Evershed, R.P. Earliest evidence for cheese making in the sixth millennium bc in northern Europe. Nat. Cell Biol. 2012, 493, 522-525. [CrossRef]

47. Rizzoli, R.; Biver, E. Effects of Fermented Milk Products on Bone. Calcif. Tissue Int. 2018, 102, 489-500. [CrossRef]

48. Rizzoli, R.; Biver, E. Are Probiotics the New Calcium and Vitamin D for Bone Health? Curr. Osteoporos. Rep. 2020, 18, $273-284$. [CrossRef] [PubMed]

49. Laird, E.; Molloy, A.M.; McNulty, H.; Ward, M.; McCarroll, K.; Hoey, L.; Hughes, C.F.; Cunningham, C.; Strain, J.J.; Casey, M.C. Greater yogurt consumption is associated with increased bone mineral density and physical function in older adults. Osteoporos. Int. 2017, 28, 2409-2419. [CrossRef]

50. Biver, E.; Durosier-Izart, C.; Merminod, F.; Chevalley, T.; Van Rietbergen, B.; Ferrari, S.; Rizzoli, R. Fermented dairy products consumption is associated with attenuated cortical bone loss independently of total calcium, protein, and energy intakes in healthy postmenopausal women. Osteoporos. Int. 2018, 29, 1771-1782. [CrossRef] [PubMed]

51. Sahni, S.; Tucker, K.; Kiel, D.; Quach, L.; Casey, V.A.; Hannan, M.T. Milk and yogurt consumption are linked with higher bone mineral density but not with hip fracture: The Framingham Offspring Study. Arch. Osteoporos. 2013, 8, 1-9. [CrossRef]

52. Burton, K.J.; Rosikiewicz, M.; Pimentel, G.; Bütikofer, U.; Von Ah, U.; Voirol, M.-J.; Croxatto, A.; Aeby, S.; Drai, J.; McTernan, P.G.; et al. Probiotic yogurt and acidified milk similarly reduce postprandial inflammation and both alter the gut microbiota of healthy, young men. Br. J. Nutr. 2017, 117, 1312-1322. [CrossRef]

53. García-Albiach, R.; José, M.; De Felipe, M.J.P.; Angulo, S.; Morosini, M.-I.; Bravo, D.; Baquero, F.; Del Campo, R. Molecular analysis of yogurt containing Lactobacillus delbrueckii subsp. bulgaricus and Streptococcus thermophilus in human intestinal microbiota. Am. J. Clin. Nutr. 2008, 87, 91-96. [CrossRef]

54. Sharifi-Rad, J.; Rodrigues, C.; Stojanović-Radić, Z.; Dimitrijević, M.; Aleksić, A.; Neffe-Skocińska, K.; Zielińska, D.; KołożynKrajewska, D.; Salehi, B.; Prabu, S.M.; et al. Probiotics: Versatile Bioactive Components in Promoting Human Health. Medicina 2020, 56, 433. [CrossRef]

55. Gilman, J.; Cashman, K.D. The effect of probiotic bacteria on transepithelial calcium transport and calcium uptake in human intestinal-like Caco-2 cells. Curr. issues Intest. Microbiol. 2006, 7, 1-5. [PubMed]

56. Terashima, A.; Takayanagi, H. Overview of Osteoimmunology. Calcif. Tissue Int. 2018, 102, 503-511. [CrossRef] [PubMed]

57. Franceschi, C.; Garagnani, P.; Parini, P.; Giuliani, C.; Santoro, A. Inflammaging: A new immune-metabolic viewpoint for age-related diseases. Nat. Rev. Endocrinol. 2018, 14, 576-590. [CrossRef] 
58. National Research Council. Diet and Health: Implications for Reducing Chronic Disease Risk; The National Academies Press: Washington, DC, USA, 1989.

59. Volpe, S.L. Magnesium and the Athlete. Curr. Sports Med. Rep. 2015, 14, 279-283. [CrossRef]

60. Matias, C.N.; Santos, D.; Monteiro, C.P.; Vasco, A.M.; Baptista, F.; Sardinha, L.; Laires, M.J.; Silva, A. Magnesium intake mediates the association between bone mineral density and lean soft tissue in elite swimmers. Magnes. Res. 2012, 25, 120-125. [CrossRef]

61. De Sousa, E.F.; Da Costa, T.H.M.; Nogueira, J.A.D.; Vivaldi, L.J. Assessment of nutrient and water intake among adolescents from sports federations in the Federal District, Brazil. Br. J. Nutr. 2008, 99, 1275-1283. [CrossRef] [PubMed]

62. Zalcman, I.; Guarita, H.V.; Juzwiak, C.R.; Crispim, C.A.; Antunes, H.K.M.; Edwards, B.; Tufik, S.; de Mello, M.T. Nutritional status of adventure racers. Nutrition 2007, 23, 404-411. [CrossRef] [PubMed]

63. Juzwiak, C.R.; Amancio, O.M.S.; Vitalle, M.S.S.; Pinheiro, M.M.; Szejnfeld, V.L. Body composition and nutritional profile of male adolescent tennis players. J. Sports Sci. 2008, 26, 1209-1217. [CrossRef] [PubMed]

64. Wierniuk, A.; Włodarek, D. Estimation of energy and nutritional intake of young men practicing aerobic sports. Roczniki Państwowego Zakładu Higieny 2013, 64, 143-148.

65. Silva, M.-R.G.; Paiva, T. Low energy availability and low body fat of female gymnasts before an international competition. Eur. J. Sport Sci. 2014, 15, 591-599. [CrossRef] [PubMed]

66. Nielsen, F.H.; Lukaski, H.C. Update on the relationship between magnesium and exercise. Magnes. Res. 2006, 19, 180-189. [PubMed]

67. Wang, R.; Chen, C.; Liu, W.; Zhou, T.; Xun, P.; He, K.; Chen, P. The effect of magnesium supplementation on muscle fitness: A meta-analysis and systematic review. Magnes. Res. 2017, 30, 120-132. [CrossRef]

68. Mittermeier, L.; Demirkhanyan, L.; Stadlbauer, B.; Breit, A.; Recordati, C.; Hilgendorff, A.; Matsushita, M.; Braun, A.; Simmons, D.G.; Zakharian, E.; et al. TRPM7 is the central gatekeeper of intestinal mineral absorption essential for postnatal survival. Proc. Natl. Acad. Sci. USA 2019, 116, 4706-4715. [CrossRef] [PubMed]

69. Luongo, F.; Pietropaolo, G.; Gautier, M.; Dhennin-Duthille, I.; Ouadid-Ahidouch, H.; Wolf, F.I.; Trapani, V. TRPM6 is Essential for Magnesium Uptake and Epithelial Cell Function in the Colon. Nutrients 2018, 10, 784. [CrossRef]

70. Funato, Y.; Yamazaki, D.; Mizukami, S.; Du, L.; Kikuchi, K.; Miki, H. Membrane protein CNNM4-dependent Mg2+ efflux suppresses tumor progression. J. Clin. Investig. 2014, 124, 5398-5410. [CrossRef]

71. Yamazaki, D.; Funato, Y.; Miura, J.; Sato, S.; Toyosawa, S.; Furutani, K.; Kurachi, Y.; Omori, Y.; Furukawa, T.; Tsuda, T.; et al. Basolateral Mg2+ Extrusion via CNNM4 Mediates Transcellular Mg2+ Transport across Epithelia: A Mouse Model. PLoS Genet. 2013, 9, e1003983. [CrossRef]

72. Kolisek, M.; Sponder, G.; Pilchova, I.; Cibulka, M.; Tatarkova, Z.; Werner, T. Magnesium Extravaganza: A Critical Compendium of Current Research into Cellular Mg(2+) Transporters Other than TRPM6/7. In Reviews of Physiology, Biochemistry and Pharmacology; Springer: Cham, Switzerland, 2019; Volume 176, pp. 65-105.

73. Pyndt Jørgensen, B.; Winther, G.; Kihl, P.; Nielsen, D.S.; Wegener, G.; Hansen, A.K. Dietary magnesium deficiency affects gut microbiota and anxiety-like behaviour in C57BL/6N mice. Acta Neuropsychiatr. 2015, 27, 307-311. [CrossRef] [PubMed]

74. Gommers, L.M.M.; Ederveen, T.; van der Wijst, J.; Bos, C.; Kortman, G.A.M.; Boekhorst, J.; Bindels, R.J.M.; de Baaij, J.; Hoenderop, J.G.J. Low gut microbiota diversity and dietary magnesium intake are associated with the development of PPIinduced hypomagnesemia. FASEB J. 2019, 33, 11235-11246. [CrossRef]

75. Zimowska, W.; Girardeau, J.P.; Kuryszko, J.; Bayle, D.; Rayssiguier, Y.; Mazur, A.; Zimowska, W.; Girardeau, J.P.; Kuryszko, J.; Bayle, D.; et al. Morphological and immune response alterations in the intestinal mucosa of the mouse after short periods on a low-magnesium diet. Br. J. Nutr. 2002, 88, 515-522. [CrossRef] [PubMed]

76. García-Legorreta, A.; Soriano-Pérez, L.A.; Flores-Buendía, A.M.; Medina-Campos, O.N.; Noriega, L.G.; Granados-Portillo, O.; Nambo-Venegas, R.; Tovar, A.R.; Mendoza-Vargas, A.; Barrera-Oviedo, D.; et al. Effect of Dietary Magnesium Content on Intestinal Microbiota of Rats. Nutrients 2020, 12, 2889. [CrossRef]

77. Kubota, M.; Ito, K.; Tomimoto, K.; Kanazaki, M.; Tsukiyama, K.; Kubota, A.; Kuroki, H.; Fujita, M.; Vandenplas, Y. Lactobacillus reuteri DSM 17938 and Magnesium Oxide in Children with Functional Chronic Constipation: A Double-Blind and Randomized Clinical Trial. Nutrients 2020, 12, 225. [CrossRef]

78. Lambert, M.N.T.; Thybo, C.B.; Lykkeboe, S.; Rasmussen, L.M.; Frette, X.; Christensen, L.P.; Jeppesen, P.B. Combined bioavailable isoflavones and probiotics improve bone status and estrogen metabolism in postmenopausal osteopenic women: A randomized controlled trial. Am. J. Clin. Nutr. 2017, 106, 909-920. [CrossRef] [PubMed]

79. Rekha, C.R.; Vijayalakshmi, G. Bioconversion of isoflavone glycosides to aglycones, mineral bioavailability and vitamin B complex in fermented soymilk by probiotic bacteria and yeast. J. Appl. Microbiol. 2010, 109, 1198-1208. [CrossRef] [PubMed]

80. Piuri, G.; Zocchi, M.; Della Porta, M.; Ficara, V.; Manoni, M.; Zuccotti, G.V.; Pinotti, L.; Maier, J.A.; Cazzola, R. Magnesium in Obesity, Metabolic Syndrome, and Type 2 Diabetes. Nutrients 2021, 13, 320. [CrossRef]

81. Maywald, M.; Wessels, I.; Rink, L. Zinc Signals and Immunity. Int. J. Mol. Sci. 2017, 18, 2222. [CrossRef]

82. Sim, M.; Garvican-Lewis, L.A.; Cox, G.; Govus, A.; McKay, A.K.A.; Stellingwerff, T.; Peeling, P. Iron considerations for the athlete: A narrative review. Eur. J. Appl. Physiol. 2019, 119, 1463-1478. [CrossRef]

83. Dahlerup, J.; Lindgren, S.; Moum, B. Iron deficiency and iron deficiency anemia are global health problems. Lakartidningen 2015, 112. [PubMed]

84. Yilmaz, B.; Li, H. Gut Microbiota and Iron: The Crucial Actors in Health and Disease. Pharmaceuticals 2018, 11, 98. [CrossRef] 
85. Gulec, S.; Anderson, G.J.; Collins, J.F. Mechanistic and regulatory aspects of intestinal iron absorption. Am. J. Physiol. Liver Physiol. 2014, 307, G397-G409. [CrossRef] [PubMed]

86. Andrews, N. The iron transporter DMT1. Int. J. Biochem. Cell Biol. 1999, 31, 991-994. [CrossRef]

87. Ward, D.M.; Kaplan, J. Ferroportin-mediated iron transport: Expression and regulation. Biochim. Biophys. Acta BBA Bioenerg. 2012, 1823, 1426-1433. [CrossRef]

88. Stoffel, N.U.; I Cercamondi, C.; Brittenham, G.; Zeder, C.; Geurts-Moespot, A.J.; Swinkels, D.W.; Moretti, D.; Zimmermann, M.B. Iron absorption from oral iron supplements given on consecutive versus alternate days and as single morning doses versus twice-daily split dosing in iron-depleted women: Two open-label, randomised controlled trials. Lancet Haematol. 2017, 4, e524-e533. [CrossRef]

89. Olivares, M.; Pizarro, F.; De Romaña, D.L. Effect of Zinc Sulfate Fortificant on Iron Absorption from Low Extraction Wheat Flour Co-Fortified with Ferrous Sulfate. Biol. Trace Element Res. 2012, 151, 471-475. [CrossRef]

90. Auerbach, M.; Schrier, S. Treatment of iron deficiency is getting trendy. Lancet Haematol. 2017, 4, e500-e501. [CrossRef]

91. Paganini, D.; Zimmermann, M.B. The effects of iron fortification and supplementation on the gut microbiome and diarrhea in infants and children: A review. Am. J. Clin. Nutr. 2017, 106, 1688S-1693S. [CrossRef]

92. Kortman, G.A.M.; Reijnders, D.; Swinkels, D.W. Oral iron supplementation: Potential implications for the gut microbiome and metabolome in patients with CKD. Hemodial. Int. 2017, 21, S28-S36. [CrossRef]

93. Lee, T.; Clavel, T.; Smirnov, K.; Schmidt, A.; Lagkouvardos, I.; Walker, A.; Lucio, M.; Michalke, B.; Schmitt-Kopplin, P.; Fedorak, R.; et al. Oral versus intravenous iron replacement therapy distinctly alters the gut microbiota and metabolome in patients with IBD. Gut 2016, 66, 863-871. [CrossRef]

94. $\mathrm{Ng}$, O. Iron, microbiota and colorectal cancer. Wien. Med. Wochenschr. 2016, 166, 431-436. [CrossRef] [PubMed]

95. Balamurugan, R.; Mary, R.R.; Chittaranjan, S.; Jancy, H.; Devi, R.S.; Ramakrishna, B. Low levels of faecal lactobacilli in women with iron-deficiency anaemia in south India. Br. J. Nutr. 2010, 104, 931-934. [CrossRef]

96. Bouglé, D.; Vaghefi-Vaezzadeh, N.; Roland, N.; Bouvard, G.; Arhan, P.; Bureau, F.; Neuville, D.; Maubois, J.-L. Influence of Short-Chain Fatty Acids on Iron Absorption by Proximal Colon. Scand. J. Gastroenterol. 2002, 37, 1008-1011. [CrossRef]

97. Das, N.K.; Schwartz, A.J.; Barthel, G.; Inohara, N.; Liu, Q.; Sankar, A.; Hill, D.R.; Ma, X.; Lamberg, O.; Schnizlein, M.K.; et al. Microbial Metabolite Signaling Is Required for Systemic Iron Homeostasis. Cell Metab. 2020, 31, 115-130. [CrossRef] [PubMed]

98. Kabak, B.; Dobson, A. An Introduction to the Traditional Fermented Foods and Beverages of Turkey. Crit. Rev. Food Sci. Nutr. 2011, 51, 248-260. [CrossRef]

99. Blandino, A.; Al-Aseeri, M.; Pandiella, S.; Cantero, D.; Webb, C. Cereal-based fermented foods and beverages. Food Res. Int. 2003 36, 527-543. [CrossRef]

100. Afify, A.E.M.M.; El-Beltagi, H.S.; Abd El-Salam, S.M.; Omran, A.A. Bioavailability of iron, zinc, phytate and phytase activity during soaking and germination of white sorghum varieties. PLoS ONE 2011, 6, e25512. [CrossRef]

101. Orozco-Mosqueda, M.D.C.; Rocha-Granados, M.D.C.; Glick, B.R.; Santoyo, G. Microbiome engineering to improve biocontrol and plant growth-promoting mechanisms. Microbiol. Res. 2018, 208, 25-31. [CrossRef] [PubMed]

102. Teng, Y.; Ren, Y.; Sayed, M.; Hu, X.; Lei, C.; Kumar, A.; Hutchins, E.; Mu, J.; Deng, Z.; Luo, C.; et al. Plant-Derived Exosomal MicroRNAs Shape the Gut Microbiota. Cell Host Microbe 2018, 24, 637-652.e8. [CrossRef] [PubMed]

103. Cai, X.; Chen, X.; Yin, N.; Du, H.; Sun., G.; Wang, L. Estimation of the bioaccessibility and bioavailability of Fe, Mn, Cu, and $\mathrm{Zn}$ in Chinese vegetables using the in vitro digestion/Caco-2 cell model: The influence of gut microbiota. Food Funct. 2017, 8, 4592-4600. [CrossRef]

104. Verma, C.; Tapadia, K.; Soni, A.B. Determination of iron (III) in food, biological and environmental samples. Food Chem. 2017, 221, 1415-1420. [CrossRef] [PubMed]

105. Lane, D.J.R.; Bae, D.-H.; Merlot, A.M.; Sahni, S.; Richardson, D.R. Duodenal Cytochrome b (DCYTB) in Iron Metabolism: An Update on Function and Regulation. Nutrients 2015, 7, 2274-2296. [CrossRef]

106. Yin, N.; Zhang, Z.; Cai, X.; Du, H.; Sun, G.; Cui, Y. In Vitro Method To Assess Soil Arsenic Metabolism by Human Gut Microbiota: Arsenic Speciation and Distribution. Environ. Sci. Technol. 2015, 49, 10675-10681. [CrossRef]

107. Luu, Y.-S.; Ramsay, J.A. Review: Microbial mechanisms of accessing insoluble Fe(III) as an energy source. World J. Microbiol. Biotechnol. 2003, 19, 215-225. [CrossRef]

108. Vonderheid, S.C.; Tussing-Humphreys, L.; Park, C.; Pauls, H.; Hemphill, N.O.; LaBomascus, B.; McLeod, A.; Koenig, M.D. A Systematic Review and Meta-Analysis on the Effects of Probiotic Species on Iron Absorption and Iron Status. Nutrients 2019, 11, 2938. [CrossRef] [PubMed]

109. Hernández-Camacho, J.D.; Vicente-García, C.; Parsons, D.S.; Navas-Enamorado, I. Zinc at the crossroads of exercise and proteostasis. Redox Biol. 2020, 35, 101529. [CrossRef] [PubMed]

110. Read, S.A.; Obeid, S.; Ahlenstiel, C.; Ahlenstiel, G. The Role of Zinc in Antiviral Immunity. Adv. Nutr. 2019, 10, 696-710. [CrossRef]

111. Huang, T.; Yan, G.; Guan, M. Zinc Homeostasis in Bone: Zinc Transporters and Bone Diseases. Int. J. Mol. Sci. 2020, 21, 1236. [CrossRef]

112. Jurowski, K.; Szewczyk, B.; Nowak, G.; Piekoszewski, W. Biological consequences of zinc deficiency in the pathomechanisms of selected diseases. J. Biol. Inorg. Chem. JBIC 2014, 19, 1069-1079. [CrossRef] [PubMed]

113. Gleeson, M. Immunological aspects of sport nutrition. Immunol. Cell Biol. 2015, 94, 117-123. [CrossRef] 
114. Micheletti, A.; Rossi, R.; Rufini, S. Zinc status in athletes: Relation to diet and exercise. Sports Med. 2001, 31, 577-582. [CrossRef]

115. Baranauskas, M.; Stukas, R.; Tubelis, L.; Žagminas, K.; Šurkienė, G.; Švedas, E.; Giedraitis, V.R.; Dobrovolskij, V.; Abaravičius, J.A. Nutritional habits among high-performance endurance athletes. Medicina 2015, 51, 351-362. [CrossRef] [PubMed]

116. Economos, C.D.; Bortz, S.S.; Nelson, M.E. Nutritional Practices of Elite Athletes. Sports Med. 1993, 16, 381-399. [CrossRef] [PubMed]

117. Schüpbach, R.; Wegmuller, R.; Berguerand, C.; Bui, M.; Herteraeberli, I. Micronutrient status and intake in omnivores, vegetarians and vegans in Switzerland. Eur. J. Nutr. 2017, 56, 283-293. [CrossRef] [PubMed]

118. Nebl, J.; Schuchardt, J.P.; Ströhle, A.; Wasserfurth, P.; Haufe, S.; Eigendorf, J.; Tegtbur, U.; Hahn, A. Micronutrient Status of Recreational Runners with Vegetarian or Non-Vegetarian Dietary Patterns. Nutrients 2019, 11, 1146. [CrossRef]

119. Heffernan, S.M.; Horner, K.; De Vito, G.; Conway, G.E. The Role of Mineral and Trace Element Supplementation in Exercise and Athletic Performance: A Systematic Review. Nutrients 2019, 11, 696. [CrossRef]

120. Wessels, I.; Rolles, B.; Rink, L. The Potential Impact of Zinc Supplementation on COVID-19 Pathogenesis. Front. Immunol. 2020, 11, 1712. [CrossRef] [PubMed]

121. Samad, N.; Sodunke, T.E.; Abubakar, A.R.; Jahan, I.; Sharma, P.; Islam, S.; Dutta, S.; Haque, M. The Implications of Zinc Therapy in Combating the COVID-19 Global Pandemic. J. Inflamm. Res. 2021, 14, 527-550. [CrossRef]

122. Nishito, Y.; Kambe, T. Absorption Mechanisms of Iron, Copper, and Zinc: An Overview. J. Nutr. Sci. Vitaminol. 2018, 64, 1-7. [CrossRef] [PubMed]

123. Umair, M.; Alfadhel, M. Genetic Disorders Associated with Metal Metabolism. Cells 2019, 8, 1598. [CrossRef]

124. Schmitt, S.; Küry, S.; Giraud, M.; Dréno, B.; Kharfi, M.; Bézieau, S. An update on mutations of theSLC39A4gene in acrodermatitis enteropathica. Hum. Mutat. 2009, 30, 926-933. [CrossRef]

125. Shusterman, E.; Beharier, O.; Shiri, L.; Zarivach, R.; Etzion, Y.; Campbell, C.R.; Lee, I.-H.; Okabayashi, K.; Dinudom, A.; Cook, D.I.; et al. ZnT-1 extrudes zinc from mammalian cells functioning as a Zn2+/H+exchanger. Metallomics 2014, 6, 1656-1663. [CrossRef] [PubMed]

126. Knezevic, J.; Starchl, C.; Berisha, A.T.; Amrein, K. Thyroid-Gut-Axis: How Does the Microbiota Influence Thyroid Function? Nutrients 2020, 12, 1769. [CrossRef]

127. Yin, N.; Cai, X.; Chen, X.; Du, H.; Xu, J.; Wang, L.; Sun, G.; Cui, Y. Investigation of bioaccessibility of Cu, Fe, Mn, and Zn in market vegetables in the colon using PBET combined with SHIME. Sci. Rep. 2017, 7, 17578. [CrossRef]

128. Intawongse, M.; Dean, J.R. Use of the physiologically-based extraction test to assess the oral bioaccessibility of metals in vegetable plants grown in contaminated soil. Environ. Pollut. 2008, 152, 60-72. [CrossRef]

129. Reed, S.; Knez, M.; Uzan, A.; Stangoulis, J.; Glahn, R.P.; Koren, O.; Tako, E. Alterations in the Gut (Gallus gallus) Microbiota Following the Consumption of Zinc Biofortified Wheat (Triticum aestivum)-Based Diet. J. Agric. Food Chem. 2018, 66, 6291-6299. [CrossRef]

130. Reed, S.; Neuman, H.; Moscovich, S.; Glahn, R.P.; Koren, O.; Tako, E. Chronic Zinc Deficiency Alters Chick Gut Microbiota Composition and Function. Nutrients 2015, 7, 9768-9784. [CrossRef] [PubMed]

131. Sauer, A.K.; Grabrucker, A.M. Zinc Deficiency During Pregnancy Leads to Altered Microbiome and Elevated Inflammatory Markers in Mice. Front. Neurosci. 2019, 13, 1295. [CrossRef]

132. Celis, A.I.; Relman, D.A. Competitors versus Collaborators: Micronutrient Processing by Pathogenic and Commensal HumanAssociated Gut Bacteria. Mol. Cell 2020, 78, 570-576. [CrossRef] [PubMed]

133. Calame, W.; Weseler, A.R.; Viebke, C.; Flynn, C.; Siemensma, A.D. Gum arabic establishes prebiotic functionality in healthy human volunteers in a dose-dependent manner. Br. J. Nutr. 2008, 100, 1269-1275. [CrossRef]

134. Zackular, J.P.; Skaar, E.P. The role of zinc and nutritional immunity in Clostridium difficile infection. Gut Microbes. 2018, 9, 469-476. [CrossRef]

135. Kang, S.; Li, R.; Jin, H.; You, H.J.; Ji, G.E. Effects of Selenium- and Zinc-Enriched Lactobacillus plantarum SeZi on Antioxidant Capacities and Gut Microbiome in an ICR Mouse Model. Antioxidants 2020, 9, 1028. [CrossRef]

136. Rayman, M.P. Selenium and human health. Lancet 2012, 379, 1256-1268. [CrossRef]

137. Mehdi, Y.; Hornick, J.-L.; Istasse, L.; Dufrasne, I. Selenium in the Environment, Metabolism and Involvement in Body Functions. Molecules 2013, 18, 3292-3311. [CrossRef] [PubMed]

138. Wardenaar, F.; Brinkmans, N.; Ceelen, I.; Van Rooij, B.; Mensink, M.; Witkamp, R.; De Vries, J. Micronutrient Intakes in 553 Dutch Elite and Sub-Elite Athletes: Prevalence of Low and High Intakes in Users and Non-Users of Nutritional Supplements. Nutrients 2017, 9, 142. [CrossRef] [PubMed]

139. Kristensen, N.B.; Madsen, M.L.; Hansen, T.H.; Allin, K.H.; Hoppe, C.; Fagt, S.; Lausten, M.S.; Gøbel, R.J.; Vestergaard, H.; Hansen, T.; et al. Intake of macro- and micronutrients in Danish vegans. Nutr. J. 2015, 14, 115. [CrossRef] [PubMed]

140. Bakaloudi, D.R.; Halloran, A.; Rippin, H.L.; Oikonomidou, A.C.; Dardavesis, T.I.; Williams, J.; Wickramasinghe, K.; Breda, J.; Chourdakis, M. Intake and adequacy of the vegan diet. A systematic review of the evidence. Clin. Nutr. 2021, 40, 3503-3521. [CrossRef]

141. McSwiney, F.; Doyle, L. Low-Carbohydrate Ketogenic Diets in Male Endurance Athletes Demonstrate Different Micronutrient Contents and Changes in Corpuscular Haemoglobin over 12 Weeks. Sports 2019, 7, 201. [CrossRef]

142. Tessier, F.; Margaritis, I.; Richard, M.J.; Moynot, C.; Marconnet, P. Selenium and training effects on the glutathione system and aerobic performance. Med. Sci. Sports Exerc. 1995, 27, 390-396. [CrossRef] [PubMed] 
143. Margaritis, I.; Tessier, F.; Prou, E.; Marconnet, P.; Marini, J.-F. Effects of Endurance Training on Skeletal Muscle Oxidative Capacities with and without Selenium Supplementation. J. Trace Elements Med. Biol. 1997, 11, 37-43. [CrossRef]

144. Shafiei Neek, L.; Gaeini, A.A.; Choobineh, S. Effect of zinc and selenium supplementation on serum testosterone and plasma lactate in cyclist after an exhaustive exercise bout. Biol. Trace Elem. Res. 2011, 144, 454-462. [CrossRef]

145. Fernández-Lázaro, D.; Fernandez-Lazaro, C.I.; Mielgo-Ayuso, J.; Navascués, L.J.; Córdova Martínez, A.; Seco-Calvo, J. The Role of Selenium Mineral Trace Element in Exercise: Antioxidant Defense System, Muscle Performance, Hormone Response, and Athletic Performance. A Systematic Review. Nutrients 2020, 12, 1790. [CrossRef]

146. Moghaddam, A.; Heller, R.A.; Sun, Q.; Seelig, J.; Cherkezov, A.; Seibert, L.; Hackler, J.; Seemann, P.; Diegmann, J.; Pilz, M.; et al. Selenium Deficiency Is Associated with Mortality Risk from COVID-19. Nutrients 2020, 12, 2098. [CrossRef] [PubMed]

147. Heller, R.A.; Sun, Q.; Hackler, J.; Seelig, J.; Seibert, L.; Cherkezov, A.; Minich, W.B.; Seemann, P.; Diegmann, J.; Pilz, M.; et al. Prediction of survival odds in COVID-19 by zinc, age and selenoprotein P as composite biomarker. Redox Biol. 2021, $38,101764$. [CrossRef]

148. Hrdina, J.; Banning, A.; Kipp, A.; Loh, G.; Blaut, M.; Brigelius-Flohé, R. The gastrointestinal microbiota affects the selenium status and selenoprotein expression in mice. J. Nutr. Biochem. 2009, 20, 638-648. [CrossRef]

149. Kasaikina, M.V.; Kravtsova, M.A.; Lee, B.C.; Seravalli, J.; Peterson, D.A.; Walter, J. Dietary selenium affects host selenoproteome expression by influencing the gut microbiota. FASEB J. 2011, 25, 2492-2499. [CrossRef] [PubMed]

150. Takahashi, K.; Suzuki, N.; Ogra, Y. Effect of gut microflora on nutritional availability of selenium. Food Chem. $2020,319,126537$. [CrossRef]

151. Zhu, H.; Zhou, Y.; Qi, Y.; Ji, R.; Zhang, J.; Qian, Z.; Wu, C.; Tan, J.; Shao, L.; Chen, D. Preparation and characterization of selenium enriched-Bifidobacterium longum DD98, and its repairing effects on antibiotic-induced intestinal dysbacteriosis in mice. Food Funct. 2019, 10, 4975-4984. [CrossRef]

152. Wastney, M.E.; Combs, G.F.; Canfield, W.K.; Taylor, P.R.; Patterson, K.Y.; Hill, A.D.; E Moler, J.; Patterson, B.H. A Human Model of Selenium that Integrates Metabolism from Selenite and Selenomethionine. J. Nutr. 2011, 141, 708-717. [CrossRef]

153. Mogna, L.; Nicola, S.; Pane, M.; Lorenzini, P.; Strozzi, G.; Mogna, G. Selenium and zinc internalized by Lactobacillus buchneri Lb26 (DSM 16341) and Bifidobacterium lactis Bb1 (DSM 17850): Improved bioavailability using a new biological approach. J. Clin. Gastroenterol. 2012, 46, S41-S45. [CrossRef] [PubMed] 